\title{
ANALISIS KELAYAKAN INDUSTRI PENYAMAKAN KULIT DI KAWASAN INDUSTRI ACEH LADONG, ACEH BESAR, ACEH
}

\author{
Adib $^{1}$, Ali Parkhan ${ }^{2}$, Taufiq Immawan ${ }^{3}$ \\ Magister Teknik Industri, Fakultas Teknologi Industri, Universitas Islam Indonesia ${ }^{1,2,3)}$ \\ Jl. Kaliurang Km. 14,5 Sleman, Yogyakarta 55501 \\ E-mail :a_db73@ymail.com
}

\begin{abstract}
The growth of industrial sector has increased. Especially for leather industries. Production of UPT Pengolahan Kulit Ladong in the form of wet blue tanned skin will be expected to cover some of the needs of national market demand. The purpose of this research is to analyze the operational feasibility of UPT Pengolahan Kulit Ladong from legal aspect, market aspect, technical aspect, management aspect, and also financial aspect. The object of this research is at UPT Pengolahan Kulit Ladong, Aceh Ladong Industrial Estate, Aceh Besar Regency, Aceh Province. The method to be used for research is techno-economical method. Data analysis consists of legal aspect analysis, market aspect analysis, technical aspect analysis, management aspect analysis, and financial aspect analysis. The results of this study indicate that in terms of legal aspects able to meet the requirements of legality, the market aspect seen from the still many unmet needs of skin that demand reached 20 million pieces of skin per year for the national market, technical aspects, to produce wet blue tanned skin can use the machine and equipment that already exist in UPT Pengolahan Kulit Ladong and already installed, management aspect that is with the availability of raw materials, it is expected when human resources are available also for UPT immediately operated and produce, and financial aspect where MARR: 10\%, NPV: Rp. 286.089.235 (NPV> 0), BEP: 96\%, PP: 4 Years 5 Months 19 Days, and IRR: $12.28 \%$, so for the operation and production of UPT Pengolahan Kulit Ladong is feasible to run based on the analysis of whole aspects.
\end{abstract}

Keyword: Wet Blue, UPT Pengolahan Kulit, Processing.

\section{PENDAHULUAN}

Perdagangan diera globalisasi ini semakin berkembang pesat, karena seiring dengan meningkatnya kebutuhan masyarakat dunia akan berbagai jenis barang dan jasa. Hal ini karena kebutuhan dan selera konsumen yang berubah, teknologi baru, daur hidup produk yang pendek dan persaingan yang semakin meningkat sehingga banyak produsen yang bersaing dalam menciptakan produk baru untuk mengikuti selera konsumen.

Perkembangan pertumbuhan sektor industri mengalami peningkatan. Khususnya untuk industri kulit. Berdasarkan (Kemenperin dan APKI), kebutuhan bahan baku untuk industri kulit dalam negeri adalah sebesar 20 juta lembar, sedangkan produksi dalam negeri hanya mampu menyediakan 5 juta lembar saja.
Kekurangan tersebut masih di impor dari berbagai negara. Meski demikian, realisasi impor hanya mencapai 2 juta lembar saja. Karena terkait dengan larangan mengimpor kulit dari berbagai negara endemi penyakit mulut dan kuku (PMK). Hal ini terjadi karena semakin meningkatnya industri padat karya yang menggunakan bahan kulit di Indonesia.

Salah satu sektor industri yang potensial untuk dikembangkan adalah industri penyamakan kulit. Industri penyamakan kulit adalah industri yang mengolah berbagai macam kulit mentah, kulit setengah jadi (kulit pikel, kulit wet blue, kulit kras) menjadi kulit jadi (Sri Waskito, 1998). Industri penyamakan kulit merupakan salah satu industri yang didorong perkembangannya sebagai penghasil devisa non migas. 
Manajemen rantai pasok dari industri kulit dimulai dari kulit mentah awet garam dari rumah pemotongan hewan, kemudian kulit awet garam tersebut diproses di industri penyamakan yang menghasilkan kulit tersamak. Terdapat bermacam - macam jenis penyamakan, salah satunya penyamakan yang menghasilkan kulit samakan wet blue, seperti yang akan dilakukan pada penelitian ini. Setelah kulit tersamak kemudian dilanjutkan ke proses untuk menghasilkan lembaran kulit jadi / finished leather yang siap digunakan untuk dijadikan produk produk yang akan digunakan end consumer.

Mengamati pada jumlah industri yang relatif padat di Pulau Jawa, maka sangat strategis untuk mengembangkan industri di luar Pulau Jawa, baik di Indonesia bagian Timur maupun Indonesia bagian Barat selain Pulau Jawa. Hal ini selaras dengan kebijaksanaan pemerintah dalam mewujudkan pemerataan pembangunan kawasan industri dan hasil - hasilnya seluruh pelosok tanah air.

Aceh yang terletak pada wilayah paling Barat Indonesia diluar Pulau Jawa merupakan daerah yang potensial untuk dijadikan sasaran pengembangan industri, mengingat sumber daya yang dimiliki baik bahan baku maupun tenaga kerja yang dimiliki. Disamping itu jaraknya yang dekat dengan pemasaran internasional melalui pelabuhan bebas Sabang merupakan potensi yang tidak dapat diabaikan dalam pengembangan pemasaran ekspor produk.

Berdasarkan informasi dari Disperindag Provinsi Aceh (2014), secara keseluruhan Aceh mampu menghasilkan 3 hingga 4 juta ton kulit dalam sehari atau sekitar 12.000.000.000 ft2 kulit tersamak wet blue. Hasil ini akan sangat baik apabila bisa diproduksi menjadi kulit jadi yang siap diekspor.

Provinsi Aceh selama ini belum mengolah kulit mentah yang dihasilkan di daerah untuk menjadi kulit jadi. Industri penyamakan kulit belum tersedia dan selama ini kulit mentah hanya dijual murah kepada daerah lain yang memiliki industri penyamakan kulit. Mengacu pada potensi yang dimiliki ini, maka sangat beralasan untuk dilakukan suatu kajian tentang pendirian industri penyamakan kulit di Kabupaten Aceh Besar, Provinsi Aceh. Dengan melakukan analisa kelayakan industri, maka diharapkan dapat memperkecil resiko kegagalan investasi yang ditanamkan.

\section{LANDASAN TEORI}

\subsection{Kulit dan Teknologi Penyamakan}

Bentuk kulit hewan berbeda - beda sesuai dengan bentuk hewannya, seperti kulit ular akan berbentuk memanjang, kulit babi akan berbentuk membundar. Secara umum bentuk kulit ular terdiri atas: daerah croupon / butt (55\%), daerah kepala dan leher (23\%), daerah perut, kaki dan ekor (22\%). Daerah croupon merupakan bagian kulit yang mempunyai mutu yang relatif paling baik dibandingkan daerah yang lainnya, karena mempunyai susunan serat yang relatif padat dan merata.

Menurut Judoamidjojo (1982), teknologi proses penyamakan kulit dapat dikelompokkan ke dalam empat tahapan, yaitu: pengawetan kulit, proses siap samak, proses penyamakan, dan proses penyelesaian.

\subsection{Studi Kelayakan}

Studi kelayakan merupakan penelitian tentang berhasil tidaknya suatu proyek yang biasanya bersifat investasi untuk dilaksanakan. Studi kelayakan digunakan untuk pendirian usaha baru baik barang maupun jasa kedalam produk mix yang sudah ada. Keberhasilan ditentukan berdasarkan tujuan lembaga yang diinginkan, dalam hal ini ada lembaga profit dan non profit yang berbeda tujuan investasinya.

Bagi lembaga profit, biasanya ukuran keberhasilannya lebih terbatas hanya kepada keuntungan secara finansial, sedangkan untuk lembaga non profit seperti pemerintah, keberhasilan diukur tidak semata - mata dari keuntungan secara finansial, tetapi juga seberapa besar penyerapan tenaga kerja, pemanfaatan sumber daya yang melimpah, 
dan faktor - faktor lainnya yang bermanfaat bagi masyarakat luas (Jumingan, 2014).

\subsection{Aspek Hukum}

Memulai studi kelayakan pada umumnya dimulai dari aspek hukum, meskipun banyak yang memulainya dari aspek lainnya. Mengenai aspek mana yang harus dimulai bergantung dari kesiapan data. Tujuan dari aspek hukum adalah untuk meneliti keabsahan, kesempurnaan, dan keaslian dari dokumen - dokumen yang dimiliki (Kasmir, 2013).

\subsection{Aspek Pasar}

Pengkajian aspek pasar penting dilakukan karena tidak ada bisnis yang berhasil tanpa adanya permintaan atas barang / jasa. Aspek pasar bertujuan antara lain untuk mengetahui berapa besar luas pasar, pertumbuhan permintaan, dan market - share dari produk bersangkutan. Bagaimana kondisi persaingan antar produsen dan siklus hidup produk juga penting untuk dianalisis. Permintaan dapat diartikan sebagai jumlah barang yang dibutuhkan konsumen yang mempunyai kemampuan untuk membeli pada berbagai tingkat harga. Penawaran diartikan sebagai kuantitas barang yang ditawarkan di pasar pada berbagai tingkat harga.

Faktor utama yang perlu dinilai dalam aspek pasar dan pemasaran (Ibrahim, 1998) adalah :

1. Jumlah permintaan produk di masa lalu dan masa kini serta kecenderungan permintaan dimasa yang akan datang.

2. Berdasarkan pada angka proyeksi (perkiraan), berapa besar kemungkinan market share yang tersedia dimasa yang akan datang.

3. Berapa market share yang direncanakan berdasar pada rencana produksi.

4. Faktor - faktor apa saja yang mungkin mempengaruhi permintaan di masa yang akan datang.

5. Strategi apa saja yang perlu dilakukan dalam meraih market share yang telah direncanakan.

\subsection{Aspek Teknis}

(Umar, 2009) Manajemen operasional adalah suatu fungsi atau kegiatan manajemen yang meliputi perencanaan, organisasi, staffing, koordinasi, pengarahan dan pengawasan terhadap operasi perusahaan. Ada tiga masalah pokok yang dihadapi perusahaan yaitu masalah penentuan posisi perusahaan, masalah desain dan masalah operasional.

Tujuan pengkajian aspek teknis (Soeharto, 2002) adalah :

1. Merumuskan gagasan yang timbul ke dalam bahasan yang bersifat konkret dari segi teknis.

2. Hasil pengkajian aspek teknis dipakai sebagai masukan dalam pengkajian aspek - aspek lainnya.

3. Desain engineering terperinci yaitu menghasilkan cetak biru (blue print) proyek yang akan dibangun.

Proses pemilihan teknologi untuk produksi, penentuan kapasitas produksi yang optimal, letak pabrik dan layout-nya dan letak usaha. Rencana pengendalian persedian bahan baku dan barang jadi. Pengawasan kualitas produk, baik dalam bentuk barang ataupun jasa.

\subsection{Aspek Manajemen}

Analisis manajemen berfungsi untuk dapat menjalankan organisasi melalui kegiatan perencanaan, pengorganisasian, pelaksanaan dan pengendalian. Aspek manajemen yang dievaluasi ada dua macam, yang pertama manajemen saat pembangunan pabrik dan yang kedua manajemen saat pabrik telah dioperasionalkan. Banyak terjadi proyek - proyek gagal dibangun atau dioperasionalkan bukan karena aspek lain, tetapi karena lemahnya manajemen. Dalam pembangunan pabrik, yang dapat ditelaah manajemennya antara lain menyusun rencana kerja, siapa saja yang terlibat, bagaimana mengkoordinasikan dan mengawasi pelaksanaan proyek dengan sebaik - baiknya. 
Sedangkan untuk telaah operasional proyek antara lain menentukan secara efektif dan efisien mengenai bentuk badan usaha, jenis - jenis pekerjaan, struktur organisasi serta pengadaan tenaga kerja yang dibutuhkan.

\subsection{Aspek Finansial}

Tujuan menganalisis aspek finansial dari analisis kelayakan usaha adalah untuk menentukan rencana investasi melalui perhitungan biaya dan manfaat yang diharapkan dengan membandingkan antara pengeluaran dan pendapat, seperti ketersediaan dana, biaya modal, kemampuan usaha untuk membayar kembali dana tersebut dalam jangka waktu yang telah ditentukan dan menilai apakah usah akan dapat dikembangkan terus (Umar, 2009).

\section{METODOLOGI PENELITIAN}

Metodologi penelitian yang dilakukan adalah meliputi analisis pada lima aspek, yaitu analisis aspek hukum, analisis aspek pasar, analisis aspek teknis, analisis aspek manajemen dan analisis aspek finansial pada UPT Pengolahan Kulit. Berikut alur penelitian yang dilakukan seperti pada gambar 1. Diagram Alir (flow chart) Penelitian.

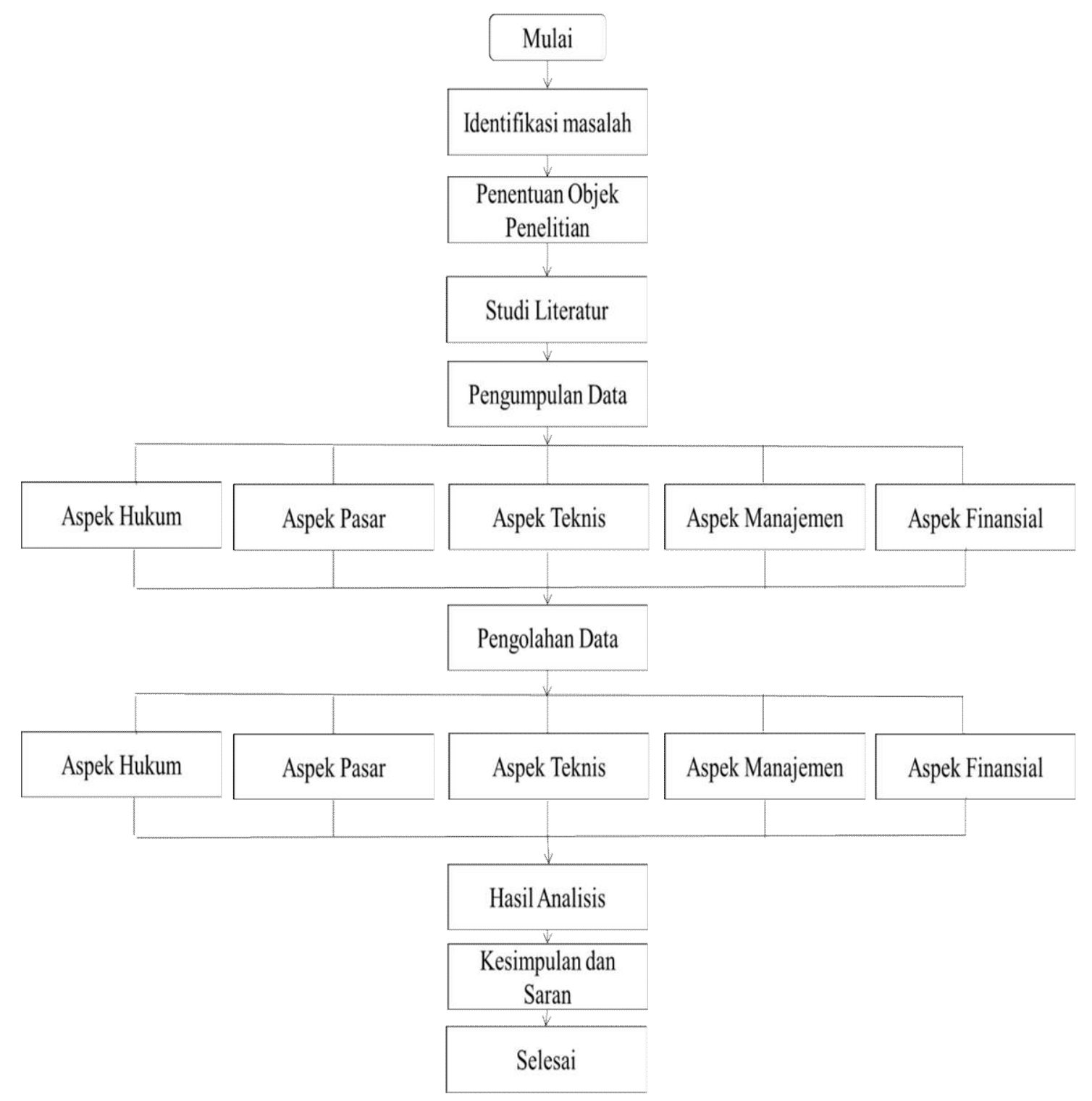

Gambar 1. Diagram Alir Penelitian. 


\section{HASIL DAN PEMBAHASAN}

\subsection{Aspek Hukum}

UPT Pengolahan Kulit Kawasan Industri Aceh Ladong ini adalah termasuk dalam kelompok perusahaan daerah. Tujuan didirikan untuk perusahaan daerah untuk turut serta melaksanakan pembangunan daerah khususnya dan pembangunan ekonomi nasional umumnya.

Untuk aspek hukum akan mengikuti Peraturan Pemerintah Republik Indonesia Nomor 14 Tahun 2015 Tentang Rencana Induk Pembangunan Industri Nasional Tahun 2015 - 2035 (RIPIN 2015 - 2035) yang sesuai dengan Pasal 5 ayat (2) Undang - Undang Dasar Negara Republik Indonesia Tahun 1945.

\subsection{Aspek Pasar}

Kulit sudah menjadi sebuah kebutuhan terutama dibidang atau industri fashion. Kebutuhan akan kulit semakin meningkat dengan semakin banyaknya tumbuh industriindustri kreatif di Indonesia. Untuk saat ini saja kebutuhan akan kulit di Indonesia masih belum terpenuhi. Kulit sendiri sudah banyak diproduksi di Indonesia, akan tetapi masih belum mampu memenuhi kebutuhan permintaan pasar lokal.

Berdasarkan analisa data yang dilakukan pada peluang pasar kulit diketahui bahwa permintaan akan kebutuhan kulit di Indonesia mencapai 20 juta lembar kulit / tahun, sementara produksi lokal hanya mampu menyediakan sebesar 5 juta lembar kulit / tahun. Sementara untuk menutupi kekurangan tersebut sisa kulit masih di impor dari luar Indonesia dan itu pun masih belum mampu menutupi akan kebutuhan pasar lokal, karena bergantung pada regulasi dan isu penyakit ternak, jadi untuk kulit yang diimpor hanya mencapai 2 juta lembar / tahun.

Mengingat masih sangat terbukanya peluang untuk pasar kulit yang mencapai 13 juta lembar / tahun dan persediannya masih sangat terbatas. Dengan demikian, prospek industri penyamakan kulit akan menjadi lebih baik untuk masa yang akan datang.

\subsection{Aspek Teknis}

4.3.1. Lokasi Usaha

Lokasi UPT Pengolahan Kulit Ladong berada di Kawasan Industri Ladong, Kabupaten Aceh Besar, Provinsi Aceh. UPT didirikan dilokasi tersebut dengan pertimbangan nantinya akan menjadi pemicu tumbuhnya industri - industri lainnya di kawasan industri tersebut dan untuk sebaran penduduk di Provinsi Aceh, khususnya Kabupaten Aceh Besar. Pertimbangan lainnya adalah dekatnya jarak dengan sumber bahan baku yang sebagian besar didatangkan dari Kabupaten Aceh Besar dan kemudahan untuk pendistribusian.

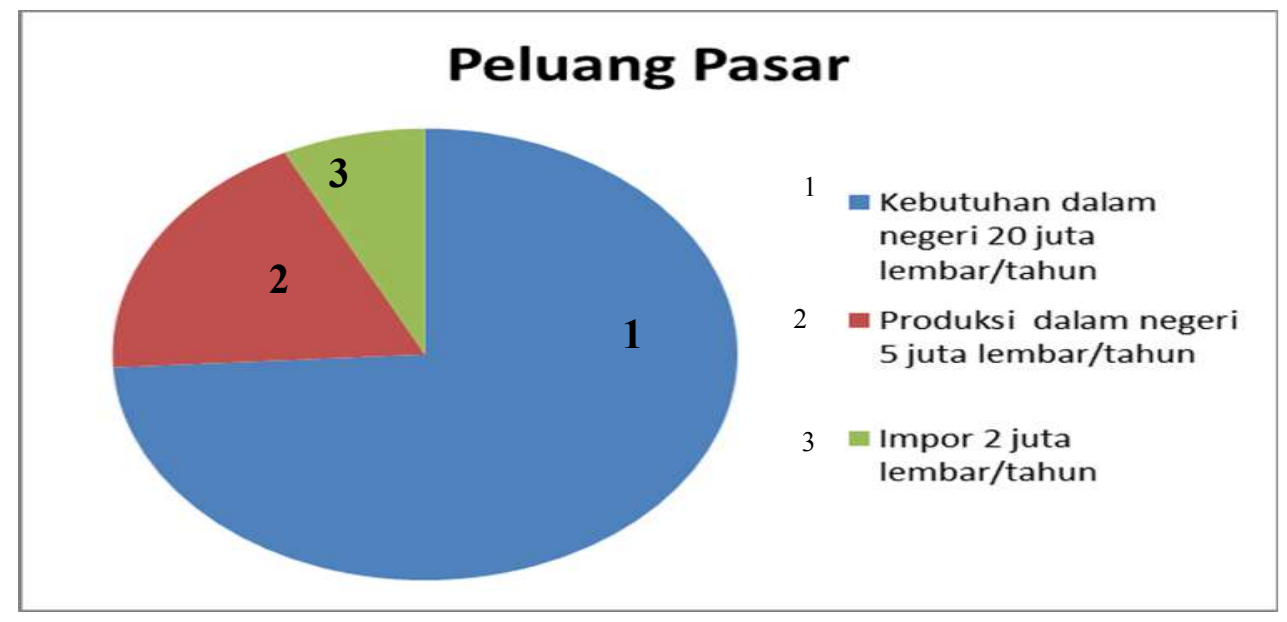

Gambar 2. Peluang Pasar Kulit. 
Tabel 1. Jumlah Kebutuhan Tenaga Kerja

\begin{tabular}{c|c|c}
\hline No & Jenis Tenaga Kerja & Jumlah \\
\hline 1 & Manajer & 1 orang \\
2 & Asisten Manajer & 2 orang \\
3 & Kepala Unit & 4 orang \\
4 & Teknisi & 6 orang \\
5 & Pembantu Umum & 2 orang \\
6 & Satpam & 1 orang \\
\hline
\end{tabular}

\subsubsection{Kondisi Pabrik}

UPT Pengolahan Kulit Ladong mempunyai luas $700 \mathrm{~m}^{2}$ dan $1600 \mathrm{~m}^{2}$ untuk bangunan kantor pelatihan dan pameran industri kulit dengan luas lahan hingga 1,7 ha. UPT memiliki kapasitas produksi sebesar 30 ton/tahun dengan 300 hari kerja efektif per tahun yang dilakukan dengan sistem 2 shift kerja per hari dan 8 jam kerja per hari. Peralatan sudah dalam keadaan terpasang dengan kapasitas produksi mencapai 30 ton / tahun. Proses pengolahan (penyamakan) kulit secara garis besar terbagi menjadi tiga proses, yaitu proses rumah basah (beamhouse), penyamakan (tanning) dan pengerjaan akhir (finishing).

\subsection{Aspek Manajemen}

\subsubsection{Kebutuhan Tenaga Kerja}

Kebutuhan tenaga kerja dalam industri penyamakan kulit dikelompokkan menjadi tenaga tetap dan tenaga kerja tidak tetap. Sedangkan untuk operasional dibagi menjadi tenaga kerja langsung dan tidak langsung. Tenaga kerja langsung merupakan tenaga kerja yang secara langsung terlibat dalam proses produksi, sedangkan tenaga kerja tak langsung adalah tenaga kerja yang tidak berhubungan secara langsung dengan proses produksi.
Tenaga kerja yang termasuk dalam kategori tenaga kerja langsung adalah teknisi, sedangkan yang termasuk dalam kategori tenaga kerja tak langsung adalah manajer, asisten manajer produksi dan pemasaran, asisten manajer umum, kepala unit produksi, kepala unit pemasaran, kepala unit keuangan, kepala unit personalia, pembantu umum, dan satpam. Rincian jenis dan jumlah tenaga kerja yang diperlukan dapat dilihat pada tabel 1 .

\subsubsection{Struktur Organisasi}

UPT Pengolahan Kulit Ladong didirikan oleh pemerintah Provinsi Aceh melalui Dinas Perindustrian dan Perdagangan Provinsi Aceh. Struktur organisasi yang digunakan pada tahap awal (kurun waktu 5 tahun ke depan) merupakan organisasi yang kecil, sehingga direkomendasikan struktur organisasi berbentuk lini. Pucuk pimpinan ada ditangan manajer. Manajer merupakan penentu kebijakan / keputusan terkait aspek produksi, pemasaran dan umum.

Dalam tugasnya manajer dibantu oleh 2 (dua) orang asisten manajer, yaitu asisten manajer produksi dan pemasaran, dan asisten manajer umum. Masing - masing asisten manajer membawahi unit - unit yang dipimpin oleh kepala unit. Unit produksi membawahi instalasi pengolahan limbah (IPAL) dan gudang. Struktur organisasi industri pengolahan kulit ini dapat dilihat pada gambar 3 . 


\subsection{Aspek Finansial}

Analisis aspek finansial pada penelitian ini dengan menggunakan kriteria kelayakan investasi dengan membandingkan biayabiaya yang digunakan dalam kegiatan pembangunan usaha yaitu biaya investasi dan biaya yang diperlukan dalam kegiatan operasional, yaitu biaya operasional.

\subsubsection{Minimum Attractive Rate of Return (MARR)}

Dari analisa finansial yang dilakukan nilai $M A R R$ ditentukan adalah $10 \%$ dengan pertimbangan suku bunga deposito di Bank Aceh sebesar 7\% karena saat ini seluruh dana Pemerintah Provinsi Aceh dikelola oleh Bank Aceh dan target keuntungan sebesar $3 \%$.

\subsubsection{Net Present Value (NPV)}

Nilai $N P V$ usaha ini bernilai positif yaitu sebesar Rp. 286.089.235 atau NPV lebih besar daripada nol.

\subsubsection{Break Event Point (BEP)}

BEP pada UPT Pengolahan Kulit ini adalah pada tingkat biaya atau jumlah produksi mencapai $96 \%$ atau berkurang sekitar 4\% dari kapasitas produksi.

\subsubsection{Payback Period (PP)}

Waktu pengembalian modal awal dari usaha ini adalah selama 4 tahun 5 bulan 19 hari. Jadi waktu pengembalian modal UPT tidak mencapai 5 tahun.

\subsubsection{Internal Rate Of Return (IRR)}

IRR dari usaha ini adalah sebesar $12,28 \%$, lebih besar dari tingkat MARR yaitu $10 \%$.

\subsubsection{Analisa Sensitivitas}

Analisa sensitivitas dari usaha ini adalah usaha tetap layak dijalankan apabila volume penjualan dan harga jual keduanya berkurang sebanyak 4\% dengan parameter lainnya tetap. Artinya usaha ini tetap stabil dan menguntungkan secara finansial apabila volume penjualan dan harga jual keduanya berkurang maksimal sampai $4 \%$.

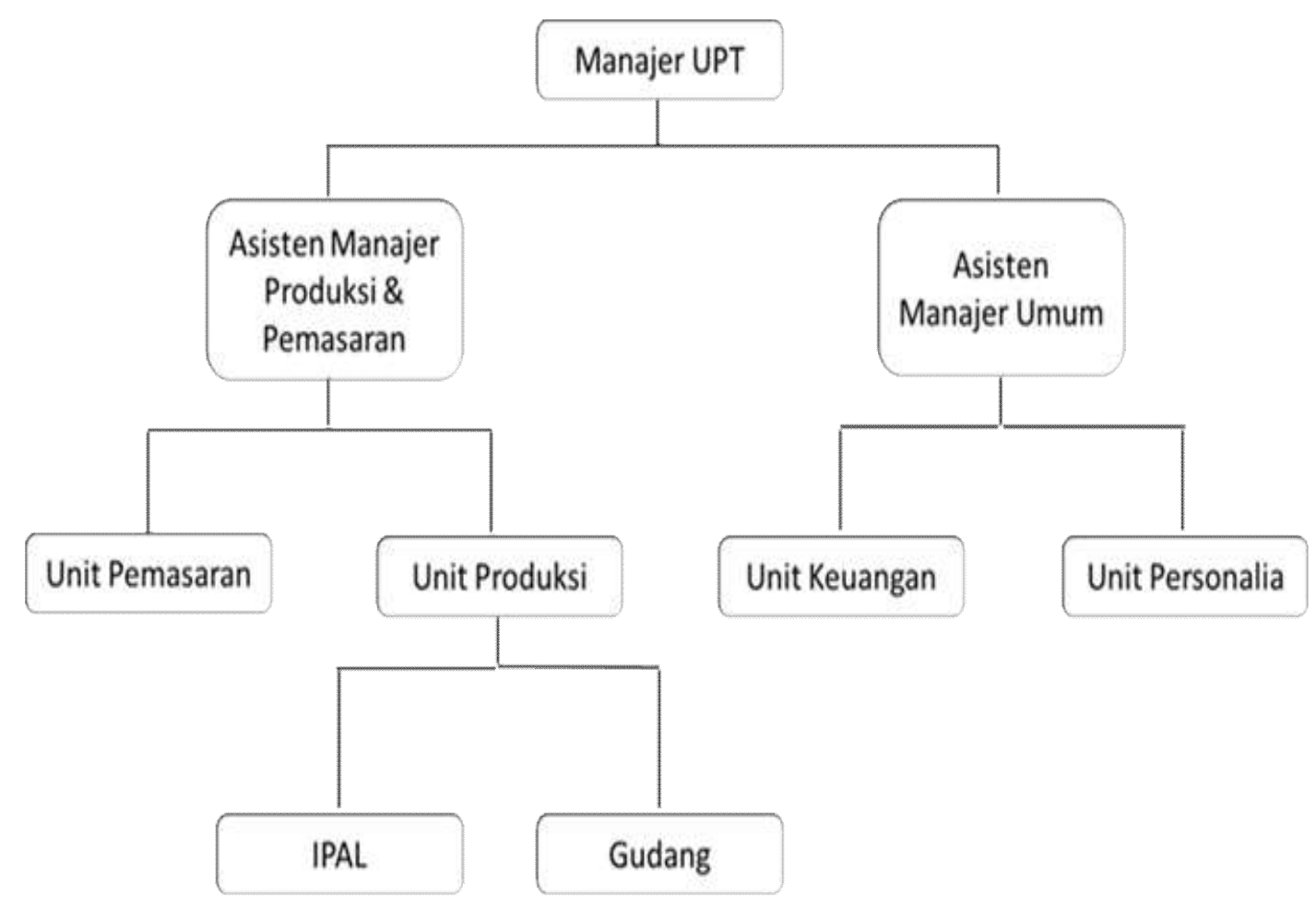

Gambar 3. Struktur Organisasi. 


\section{KESIMPULAN}

Berdasarkan hasil pengolahan data dan analisis data yang telah dilakukan, maka dapat ditarik kesimpulan :

1. Aspek hukum dari UPT Pengolahan Kulit Ladong sudah sangat jelas mengenai bentuk badan hukumnya, dikarenakan UPT ini merupakan perusahaan yang didirikan oleh Pemerintah Provinsi Aceh dan dalam bentuk perusahaan daerah. Jadi secara hukum UPT ini sudah mampu memenuhi persyaratan sehingga dikatakan layak untuk dioperasikan.

2. Aspek pasar dari UPT Pengolahan Kulit Ladong memiliki prospek yang sangat besar dan masih sangat terbuka peluangnya, mengingat masih banyak belum terpenuhinya permintaan pasar nasional akan kebutuhan kulit yang mencapai 13 juta lembar / tahun.

3. Berdasarkan aspek teknis UPT Pengolahan Kulit Ladong sudah sangat siap untuk melakukan proses produksi dengan semua peralatan yang sudah terpasang.

4. Dari aspek manajemen dan operasi dilihat dari ketersediaan bahan baku dan telah tersedianya mesin untuk produksi, maka ketika sumber daya manusia sudah tersedia juga maka UPT dapat segera dioperasikan.

5. Berdasarkan analisa aspek finansial yang telah dilakukan, maka dapat diambil kesimpulan bahwa dengan MARR 10\% usaha ini menguntungkan dan layak untuk dijalankan dengan perhitungan parameter kelayakan yang menunjukkan hasil sebagai berikut :
a. NPV $=>0$ (usaha layak untuk dijalankan).
b. $\mathrm{BEP}=$ pada tingkat biaya atau jumlah produksi mencapai $96 \%$.
c. $\mathrm{PP}=4$ tahun 5 bulan 19 hari dari perencanaan usaha minimal 5 tahun.
d. $\operatorname{IRR}=12,28 \%$.

Berdasarkan analisa sensitivitas usaha UPT tetap stabil dan menguntungkan apabila volume penjualan berkurang sebanyak 4\% dengan parameter yang lainnya tetap.

\section{DAFTAR PUSTAKA}

Disperindag. Provinsi Nanggroe Aceh Darussalam., 2014.

Ibrahim. Y. Studi Kelayakan Bisnis. Jakarta: Rineka Cipta., 1998.

Judoamidjojo, R. M. Dasar Teknologi dan Kimia Kulit. FATETA - IPB, Bogor., 1982.

Jumingan. Studi Kelayakan Bisnis: Teori \& Pembuatan Proposal Kelayakan. Bumi Aksara, Jakarta., 2014.

Kasmir \& Jakfar. Studi Kelayakan Bisnis, Kencana, Jakarta., 2013.

Kemenperin, http : //www.kemenperin.go.id lartikel/9313/Industri-KulitTerkendala-Bahan-Baku.

Soeharto, I. Studi Kelayakan Proyek Industri. Jakarta: Erlangga., 2002.

Umar, H. Studi Kelayakan Bisnis. Penerbit PT.Gramedia Pustaka Utama, Jakarta., 2009.

Waskito, S. Teknologi Peyamakan Kulit. Balai Besar Kulit Karet dan Plastik, Yogyakarta., 1998. 